\title{
Frequent grazing by sheep reduced caucasian clover cover and rhizome mass in ryegrass pasture
}

\author{
R.J. LUCAS, A.J.E. MOORHEAD, W.W. NICHOL, J.R. SEDCOLE and P. JARVIS \\ Division of Soil, Plant and Ecological Sciences, PO Box 84, \\ Lincoln University, Canterbury, New Zealand
}

\begin{abstract}
The responses of hexaploid caucasian clover (Trifolium ambiguum) to four contrasting grazing regimes were compared with those of white clover (T. repens) in an endophytic (Neotyphodium lolii) hybrid ryegrass pasture on a fertile lowland site. After 2 years, frequent grazing (set stocking) by sheep reduced caucasian clover cover to $10 \%$ compared with $25.5 \%$ in infrequent grazing (rotational grazing) treatments (mean spelling time 25 days). Similarly, frequent grazing reduced caucasian clover rhizome plus root dry weight ( 780 $\mathrm{kg} \mathrm{DM} / \mathrm{ha}$ when sampled to $100 \mathrm{~mm}$ depth in frequently grazed plots, compared with $3220 \mathrm{~kg}$ $\mathrm{DM} /$ ha for infrequent). Under frequent grazing treatments, mean white clover cover was $21 \%$, under infrequent hard grazing it was $26 \%$ and under lax infrequent grazing it was $14 \%$. The reduction in ryegrass tiller population from $5720 / \mathrm{m}^{2}$ in the infrequently and laxly grazed treatments to 4150 / $\mathrm{m}^{2}$ in the frequently hard grazed pastures indicated the severity of that hard grazed treatment. These results show that in lowland ryegrass pastures on high fertility sites, the stoloniferous growth form of white clover may be superior to the rhizomatous strategy of caucasian clover when grazing by sheep is frequent throughout spring, summer and autumn.
\end{abstract}

Keywords: caucasian clover, cover, grazing frequency, grazing intensity, kura clover, rhizomes, ryegrass, Trifolium ambiguum, Trifolium repens, white clover

\section{Introduction}

Caucasian clover is recognised in New Zealand and Australia for its potential as a persistent legume in rangeland (Allan \& Keoghan 1994; Virgona \& Dear 1996). Seed of hexaploid caucasian clover cultivars is now available and sowings are being promoted beyond the well-demonstrated rangeland niche. Information is therefore required on the agronomy of caucasian clover for lowland pastures and its grazing requirements under high stocking rates in intensively managed pastoral systems.
Few experiments on caucasian clover defoliation from fertile lowland sites have been reported: Stewart \& Daly (1980) showed monthly cutting produced about $20 \%$ less tetraploid caucasian clover than bi-monthly cuts; Sheaffer et al. (1992) in Minnesota showed hexaploid caucasian clover was an aggressive competitor against Lotus corniculatus under lenient rotational grazing by sheep; Petersen et al. (1994a), also in Minnesota, showed a $30 \%$ reduction in yield with six cuts per growing season compared with three cuts in pure caucasian clover stands in the third year of their study after little difference in the first 2 years. They also showed that sheep grazing with 14- and 28-day spelling periods resulted in successive decreases in total forage production over a 3-year period. Nevertheless, they concluded that caucasian clover tolerates frequent and close defoliation.

None of those experiments challenged caucasian clover with frequent intensive grazing in the presence of an aggressive pasture grass or a grazing tolerant legume. An experiment with four contrasting grazing treatments was therefore initiated in 1992 to compare caucasian clover with white clover in a dense ryegrass sward of high endophyte status on a fertile soil.

\section{Materials and methods}

This grazing experiment is located on a flat site $(11 \mathrm{~m}$ a.s.1.) at Lincoln University ( $\left.43^{\circ} 39^{\prime} \mathrm{S}, 172^{\circ} 28^{\prime} \mathrm{E}\right)$. The Templeton sandy silt loam has variable depth $(600$ $1500 \mathrm{~mm}$ ) over gravel, pH 5.4 and Olsen P 16.

Rainfall was supplemented with irrigation to ensure pasture production did not cease during dry summers. The site received a total of approximately $900 \mathrm{~mm}$ rain plus irrigation in both years (1993/94 and 1994/95). Mean soil temperatures at $100 \mathrm{~mm}$ depth ranged between $17^{\circ} \mathrm{C}$ in February and $2^{\circ} \mathrm{C}$ in July.

Hexaploid caucasian clover (Trifolium ambiguum $\mathrm{cv}$. Monaro) and three other lines of rhizomatous clovers were sown on 22 March 1989 in rows, $0.75 \mathrm{~m}$ apart, at 100 viable seeds $/ \mathrm{m}$ row for a seed production investigation. There were four rows per plot with $0.75 \mathrm{~m}$ between plots. The plots were $80 \mathrm{~m}$ long and $3 \mathrm{~m}$ wide to allow for proposed mechanical seed harvesting. The four legume treatments were replicated three times to give an experimental area of about $80 \times 52 \mathrm{~m}$. This 
earlier study ceased after 3 years because of the vigour of adventive white clover (T. repens) from seed reserves in the soil.

Hybrid ryegrass (Lolium $\times$ boucheanum syn. $L$. hybridum cv Marsden) with a high level of lolium endophyte (Neotyphodium lolii) was drilled at $15 \mathrm{~kg}$ seed/ha into the clover turf in spring 1992. After successful grass establishment the area was rotationally grazed by sheep until August 1993. In early spring 1993, the area was fenced across the rhizomatous clover plots to give eight plots of $52 \times 10 \mathrm{~m}$. Each of these grazing treatment main plots contained 12 rhizomatous clover sub-plots $(10 \times 3 \mathrm{~m})$ with strips of adventive white clover between each sub-plot.

Four grazing treatments were applied in spring, summer and autumn of 1993/94 and 1994/95. All plots were grazed to a low pasture mass of $700 \mathrm{~kg} \mathrm{DM} / \mathrm{ha}$ each winter.

The two factors in the experimental design were grazing frequency (set stocking vs rotational grazing which had 4-day grazing durations and about 25-day spells) and grazing intensity (hard and lax). Pastures were managed to achieve pasture masses of between 600 and $1000 \mathrm{~kg} \mathrm{DM} / \mathrm{ha}$ for hard set stock and 1500 $2500 \mathrm{~kg} \mathrm{DM} / \mathrm{ha}$ for lax set stock. Rotationally grazed treatments had pre- and post-grazing pasture masses of about 2000 and $600 \mathrm{~kg} \mathrm{DM} / \mathrm{ha}$ for rotational hard and 3000 and $1800 \mathrm{~kg} \mathrm{DM} / \mathrm{ha}$ for rotational lax. Because the plots were limited in area $\left(520 \mathrm{~m}^{2}\right)$, set stocking with a minimum flock size of three ewe hoggets was achieved during periods of low pasture production by rotationally grazing the hard set stock plots for durations of 4 or 5 days and then the lax set stock plots for 2 or 3 days. The set stocked plots therefore had spelling times of 2-5 days during low pasture production periods.

This paper reports results of caucasian clover and white clover sub-plots only.

Cover was determined by placing the point analyser at right angles across the clover rows in the replicates of the caucasian clover sub-plots within each of the grazed plots. White clover was sampled from pasture areas immediately adjacent to the caucasian clover sub-plots. Underground biomass was sampled by taking eight cores (50 $\mathrm{mm}$ diameter $\times 100 \mathrm{~mm}$ deep) per sub-plot within the original drill rows in August 1995.

\section{Results}

During the first year of grazing caucasian clover had similar cover to white clover in set stocked treatments and was superior to white clover in the rotationally grazed treatments (Table 1). Cover changed during the second year and by the end of the second year, caucasian clover cover was about half that of the white clover in set stocked treatments with hard set stock being most severely affected. In contrast caucasian clover cover was greater than white clover under lax rotational grazing while both clovers had similar cover values under hard rotational grazing.

Table 1 Changes in caucasian and white clover based endophytic ryegrass pastures under four contrasting grazing regimes over two years.

\begin{tabular}{|c|c|c|c|c|c|c|}
\hline \multirow{3}{*}{\multicolumn{2}{|c|}{ Pasture component }} & \multicolumn{5}{|c|}{--- Grazing treatment - } \\
\hline & & \multicolumn{2}{|c|}{ Set stock } & \multicolumn{2}{|c|}{ Rotational grazing } & \multirow[b]{2}{*}{ SED } \\
\hline & & Hard & Lax & Hard & Lax & \\
\hline \multicolumn{2}{|c|}{$\begin{array}{l}\text { Mean grazing pressure } \\
\text { (grazing days/ha) }\end{array}$} & 480 & 330 & 700 & 350 & \\
\hline \multicolumn{7}{|c|}{ First grazing year } \\
\hline Cover & Caucasian & 14 & 14 & 21 & 17 & 1.7 \\
\hline \multirow[t]{3}{*}{$(\%)$} & White & 16 & 11 & 7 & 5 & 2.3 \\
\hline & Grass & 53 & 62 & 59 & 68 & 2.8 \\
\hline & Others & 17 & 13 & 13 & 10 & - \\
\hline \multicolumn{7}{|c|}{ October 1995, after 2 years grazing } \\
\hline Cover & Caucasian & 7 & 13 & 28 & 23 & 2.2 \\
\hline \multirow[t]{2}{*}{$(\%)$} & White & 18 & 24 & 26 & 14 & 2.8 \\
\hline & Weed & 24 & 4 & 8 & 6 & - \\
\hline \multicolumn{7}{|c|}{ Underground biomass } \\
\hline \multirow[t]{2}{*}{ (t/ha) } & Caucasian & 0.5 & 1.1 & 3.7 & 2.7 & 0.50 \\
\hline & Ryegrass & 2.5 & 3.3 & 2.2 & 2.8 & 0.62 \\
\hline $\begin{array}{l}\text { Tillers } \\
\left(\mathrm{no} . / \mathrm{m}^{2}\right)\end{array}$ & Ryegrass & 4150 & 5750 & 5700 & 5710 & 780 \\
\hline
\end{tabular}

After 2 years the underground caucasian clover biomass values were proportional to leaf cover. Under hard set stocking, root plus rhizome biomass was most depleted, while hard rotational grazing had over seven times the underground biomass. More roots of ryegrass (3.0 t DM/ha to $100 \mathrm{~mm}$ depth) were extracted from soil cores sampled from laxly grazed plots compared with $2.3 \mathrm{t}$ in hard grazed plots, but the difference was not significant $(\mathrm{P}=0.2)$.

The sward characteristics in October 1995, 2 years after grazing treatments started, showed the severity of the hard set stock treatment as indicated by reduced ryegrass tiller numbers and the invasion of weeds into the "overgrazed" pasture (Table 1). In the previous autumn there was significantly more bare ground in set stocked plots and both lax grazed treatments had a high proportion of dead leaf and reproductive stem.

\section{Discussion}

Contrary to expectation, the present results showed that caucasian clover cover was adversly affected by set stocking compared with white clover. The reduction in caucasian clover cover was correlated with a reduction in underground biomass under set stocking. Both clovers were productive under hard rotational grazing but caucasian was more tolerant of the high pasture mass in the lax rotationally grazed plots. 
Other grazing studies have indicated that caucasian clover may be sensitive to frequent defoliation but none have used such severe treatments nor have they shown such large differences between treatments. Our experiment challenged caucasian clover plants with competition from endophyte infected ryegrass, white clover and selective grazing by sheep from September to May over 2 years.

The greatest underground biomass sampled to a depth of $100 \mathrm{~mm}$ after 2 years of the grazing treatments in the 6-year-old Monaro caucasian plants was $3.7 \mathrm{t}$ $\mathrm{DM} / \mathrm{ha}$ in the hard rotational treatment and only $0.5 \mathrm{t}$ in the hard set stock treatment. These values are much less than the $20 \mathrm{t} \mathrm{DM} / \mathrm{ha}$ to a depth of $200 \mathrm{~mm}$ underground biomass from a 14-year-old, ungrazed, well fertilised, Canterbury high country site reported by Strachan et al. in 1994. Peterson et al. (1994b) reported a $20 \%$ mean decrease from $7.5 \mathrm{t}$ to $6 \mathrm{t} \mathrm{DM} / \mathrm{ha}$ in below ground biomass (sampled to $150 \mathrm{~mm}$ ) during the second year of their cutting experiment but the three, four, five and six cuts/season had little effect. Peterson et al. (1994b) claimed that their frequent grazing of a caucasian clover monoculture had little effect on below ground biomass, but they did in fact have greater underground biomass in their 28-day spelling treatment than in their 14-day treatment. In an 11-year-old site at Lincoln University adjacent to the grazing trial described in this paper, we measured $7.5 \mathrm{t}$ $\mathrm{DM} / \mathrm{ha}$ to $150 \mathrm{~mm}$ of underground biomass in December 1997 from Monaro caucasian clover plots (Lucas unpublished); these plots were initially used for seed production studies (Daly et al. 1993) but had been invaded by annual grasses and grazed four or five times per year for 6 years before sampling.

These reports suggest that although caucasian clover may develop a very large underground biomass of roots and rhizomes when ungrazed, grazing and competition from other plant species deplete its underground reserves. The response to frequent defoliation in caucasian clover has similarities to tap-root depletion and decreased herbage production observed in lucerne, red clover and chicory.

The results from our grazing experiment were not expected because rhizomes were perceived to be the ultimate grazing avoidance strategy for very palatable pasture species (Forde et al. 1989). Also, the depletion of caucasian clover rhizomes and roots under a frequent severe grazing regime was perplexing, as there are large areas in eastern Turkey where caucasian clover maintains a strong presence in spite of having been grazed for millennia (A.H. Nordmeyer pers. comm.).

The depletion of rhizomes and roots under severe frequent grazing (hard set stock) for the full growing season from spring to early winter suggests that persistence of caucasian clover may be compromised under this extreme management. Further work is required on the productivity and persistence of caucasian clover under less extreme, more typical grazing management. For instance, New Zealand sheep farmers usually set stock ewes and lambs in spring but rotationally graze for the rest of the year. This sheep farming grazing regime, which includes summer and autumn rotational grazing, should suit the apparent need for caucasian clover to be spelled so it can recover and/or maintain its underground biomass.

\section{Conclusions}

Caucasian clover may be better adapted to rotational grazing than white clover, but set stocking will reduce its cover and underground biomass, the amount of reduction depending on grazing intensity.

\section{REFERENCES}

Allan, B.E.; Keoghan, J.M. 1994. More persistent legumes and grasses for oversown tussock country. Proceedings of the New Zealand Grassland Association 56: 143-147.

Daly, G.T.; Gurung, J.; Lucas, R.J. 1993. Stand age and closing date effects on seed yield of caucasian clover and zigzag clover cultivars. Proceedings of the XVII International Grassland Congress: 1664-1666.

Forde, M.B.; Hay, M.J.M.; Brock, J.L. 1989. Development and growth characteristics of temperate perennial legumes. pp. 91-109. In: G.C. Marten et al. Persistence of forage legumes. Proc. Australian/ New Zealand/United States Workshop, Honolulu, July 1988. ASA, CSSA and SSSA, Madison, WI.

Peterson, P.R.; Sheaffer, C.C.; Jordan, R.M.; Christians, C.J. 1994a. Responses of kura clover to sheep grazing and clipping: 1 . Yield and forage quality. Agronomy journal 86: 655-660.

Peterson, P.R.; Sheaffer, C.C.; Jordan, R.M.; Christians, C.J. 1994b. Responses of kura clover to sheep grazing and clipping: 2. Below-ground morphology, persistence and total nonstructural carbohydrates. Agronomy journal 86: 660-667.

Sheaffer, C.C.; Marten, G.C.; Jordan, R.M.; Ristau, E.A. 1992. Forage potential of kura clover and birdsfoot trefoil when grazed by sheep. Agronomy journal 84: 176-180.

Stewart, A.V.; Daly, G.T. 1980. Growth of an established stand of Trifolium ambiguum in a fertile lowland environment. New Zealand journal of experimental agriculture 8: 255-257.

Strachan, D.E.; Nordmeyer, A.H.; White, J.G.H. 1994. Nutrient storage in roots and rhizomes of hexaploid 
caucasian clover. Proceedings of the New Zealand Grassland Association 56: 97-99.

Virgona, J.M.; Dear, B.S. 1996. Comparative performance of caucasian clover (Trifolium ambiguum cv. Monaro) after 11 years under low-input conditions in south-eastern Australia. New Zealand journal of agricultural research 39: 245-253. 